\title{
Ionic Liquids as Designer Solvents for Nucleophilic Aromatic Substitutions.
}

Ian Newington, ${ }^{\mathrm{a}}$ Juan M. Perez-Arlandis ${ }^{\mathrm{b}}$ and T. Welton ${ }^{1, \mathrm{~b}}$

${ }^{a}$ Current address: GE Healthcare Bio-Sciences, The Grove Centre, White Lion Road

Amersham, HP7 9LL.

${ }^{\mathrm{b}}$ Imperial College of Science Technology and Medicine, South Kensington, London SW7 2AZ. UK

\section{Experimental}

\section{Chromatographic system and conditions}

The HPLC system used for the analysis of the samples was a Perkin Elmer 250 Binary LC pump with a SSI 500 detector variable UV/Vis and $20 \mu \mathrm{L}$ injection loop. The column attached was a Phenomenex LUNA $3 \mu \mathrm{m}$ C18(2) 150 x $4.60 \mathrm{~mm}$ [00F-4251-E0]. The UV detector was set at $224 \mathrm{~nm}$ which was found to be the most suitable wavelength for the detection of all the substrates, product and internal standard. The flow-rate of the mobile phase was adjusted to between 0.8 and $1.0 \mathrm{~mL} / \mathrm{min}$ to keep the column pressure between 2600 - 2800 p.s.i. The system was not thermostated, therefore all the measurements were carried out at ambient temperature. Chromatograms were recorded in a computer system using CWS32 v.1.4.11.56 software from DataApex.

\section{General experimental procedure for the $S_{N} A r$ reactions}

All the reactions reported were carried out in a Radleys Discovery Technologies multireaction carrousel system. Up to twelve reactions could be carried out under nitrogen at the same temperature and stirring rate.

Reagents used in this experiment were obtained from Lancaster and Aldrich. Ionic liquids based on trifluoroacetate were donated by EMD chemical - Merck KGaA ([C $\left.{ }_{4} \mathrm{C}_{1} \mathrm{im}\right]\left[\right.$ TFA] Ref. 491158 and $\left[\mathrm{C}_{4} \mathrm{C}_{1}\right.$ pyrr][TFA] Ref. 49157).

\footnotetext{
${ }^{1}$ To whom correspondence should be addressed, t.welton@imperial.ac.uk
} 


\section{$\underline{\text { Reaction mixture preparation with no added base }}$}

To a nitrogen flushed carrousel tube containing $p$-anisidine $(0.12 \mathrm{~g}, 0.97 \mathrm{mmol}, 1.04$ eq.), $1 \mathrm{~mL}$ of thoroughly dried ionic liquid was added using a disposable syringe. Then with the aid of a micro-syringe, $100 \mu \mathrm{L}$ of 4 -fluoronitrobenzene $(0.133 \mathrm{~g}, 0.94 \mathrm{mmol}$, 1eq.) were added into the reaction mixture through the tube's suba-seal. Once the carrousel system was stabilised at $100^{\circ} \mathrm{C}$, the tubes were connected to the nitrogen line at paraffin pressure and the reaction was allowed to react with continuous stirring for 24 hours. After this time the hot plate was tuned of and the reactor was allowed to reach room temperature.

\subsubsection{Reaction mixture preparation with added base}

The experimental procedure in this case was very similar but with small modifications depending on the nature of the base. For those bases that were not hygroscopic they were added after the addition of the arylhalide. The amount of base added was in all cases $10 \%$ molar ratio relative to the arylhalide. For those bases that required the use of glovebox due to their hygroscopic nature, then the order of the addition of the reagents was modified. Into the glove-box $p$-anisidine was weighed out and afterwards the required amount of base was added. The sealed tube was the taken out of the glove-box and $1 \mathrm{~mL}$ of dried ionic liquid was added followed by 4-fluoronitrobenzene.

\section{Preparation of the samples for HPLC injection}

Once the reaction was finished and cooled to room temperature, the reaction mixture was dissolved by adding approximately $16 \mathrm{~mL}$ of methanol. The mixture was allowed to dissolve with continuous stirring and sonication when necessary. Then, the required amount of the internal standard (dibutyl phthalate, $250 \mu \mathrm{L}$ ) was added to the methanol mixture and continuous stirring ensured the homogenisation of the mixture. This mixture could not be directly injected into the HPLC since the signal for the substrates appeared over the detector limits. Therefore, to operate in an adequate range of detection, $1.5 \mathrm{~mL}$ of the methanol mixture was added in a $50 \mathrm{~mL}$ volumetric flask and then was topped up with methanol. The sample was degassed in an ultrasound bath and it was then ready for injection. The order and time of elution observed was in most cases; $p$-anisidine and 
ionic liquid (1 - $2 \mathrm{~min})$, then 4-fluoronitrobenzene ( $3 \mathrm{~min})$, then the desired product ( 4-5 $\mathrm{min})$ and the last peak to appear was be the standard ( $13 \mathrm{~min})$.

\section{Isolation of 4'-methoxy-4-nitrodiphenylamine}

The reaction mixture was dissolved in dichloromethane and it was taken into a separating funnel. The organic layer was washed four times with aliquots of water. Each aliquot of water was then taken into another funnel and was extracted with ether. The ether and $\mathrm{CH}_{2} \mathrm{Cl}_{2}$ phase were mixed and the solvents were removed in the rotatingevaporator. The residue obtained was chromatographed on silica eluting with petrol (60$80^{\circ} \mathrm{C}$ ) / dichloromethane mixtures. The fraction containing the orange product was evaporated and the residue was recrystallised from petrol to obtain red needles. No yield was calculated.

- $\delta_{\mathrm{H}}\left(400 \mathrm{MHz}, \mathrm{DMSO}-d^{6}\right) / \mathrm{ppm} 3.74\left(3 \mathrm{H}, \mathrm{s},-\underline{\mathrm{C}}_{3}\right), 6.87\left(2 \mathrm{H}, \mathrm{d}, \mathrm{H}_{3}{ }^{\prime} \mathrm{H}_{5}{ }^{\prime}, J=9.2 \mathrm{~Hz}\right)$, $6.97\left(2 \mathrm{H}, \mathrm{d}, \mathrm{H}_{2}{ }^{\prime} \mathrm{H}_{6}{ }^{\prime}, J=8.8 \mathrm{~Hz}\right), 7.17\left(2 \mathrm{H}, \mathrm{d}, \mathrm{H}_{2} \mathrm{H}_{6}, J=8.7 \mathrm{~Hz}\right), 8.03\left(2 \mathrm{H}, \mathrm{d}, \mathrm{H}_{3} \mathrm{H}_{5}, J=\right.$ 9.1Hz), $9.11(1 \mathrm{H}, \mathrm{s},-\mathrm{N} \underline{\mathrm{H}}-)$.

- $\delta_{\mathrm{C}}\left(100 \mathrm{MHz}, \mathrm{DMSO}-d^{6}\right) / \mathrm{ppm} 55.27\left(\mathrm{~s}, \mathrm{C}_{4}\right.$,,$\left.-\underline{\mathrm{CH}}_{3}\right), 112.27\left(\mathrm{~s}, \mathrm{C}_{6} \mathrm{C}_{2},-\underline{\mathrm{CH}}=(\mathrm{CNH}-)-\right.$ $\underline{\mathrm{C}}=), 114.76\left(\mathrm{~s}, \mathrm{C}_{3}{ }^{\prime} \mathrm{C}_{5}{ }^{\prime},-\underline{\mathrm{CH}}=(\mathrm{CO}-)-\underline{\mathrm{CH}}=\right), 124.00$ (s, $\left.\mathrm{C}_{2}{ }^{\prime} \mathrm{C}_{6}{ }^{\prime},-\underline{\mathrm{CH}}=(\mathrm{CNH}-)-\underline{\mathrm{CH}}=\right)$, $126.30\left(\mathrm{~s}, \mathrm{C}_{5} \mathrm{C}_{3},-\underline{\mathrm{C}} \mathrm{H}=\left(\mathrm{CNO}_{2}\right)-\underline{\mathrm{C}} \mathrm{H}=\right), 132.50\left(\mathrm{~s}, \mathrm{C}_{1}\right.$,,$\left.=\underline{\mathrm{CNH}}-\right), 137.10\left(\mathrm{~s}, \mathrm{C}_{4},=\underline{\mathrm{CNO}_{2}-}\right)$, $152.13\left(\mathrm{~s}, \mathrm{C}_{1},=\underline{\mathrm{CNH}}-\right)$ ) and $156.13\left(\mathrm{~s}, \mathrm{C}_{4}{ }^{\prime},=\underline{\mathrm{CO}}-\right.$ ).

- $\mathrm{m} / \mathrm{z}\left(\mathrm{FAB}^{+}\right) 244\left(\mathrm{M}^{+}, 100 \%\right), 245\left(\mathrm{M}^{+}+1,75 \%,\right), 246\left(\mathrm{M}^{+}+2,13 \%\right)$.

- $\mathrm{C}_{13} \mathrm{H}_{12} \mathrm{~N}_{2} \mathrm{O}_{3}$ requires $\mathrm{C} 63.93 \%, \mathrm{H} 4.95 \%$ and $\mathrm{N} 11.47 \%$ found $\mathrm{C} 63.84 \%, \mathrm{H} 4.84 \%$ and $\mathrm{N} 11.54 \%$. 
